\title{
Factors Influencing Hazardous Street Trees at Selected City Council in Malaysia
}

\author{
Ramly Hasan*, Noriah Othman, Faridah Ismail \\ Faculty of Architecture, Planning and Surveying, \\ Universiti Teknologi MARA,40450 Shah Alam, Selangor, Malaysia \\ ramlyhasan80@yahoo.com
}

\begin{abstract}
Street trees are an important part of city development. Proper tree management provides conducive environment for socialization. Previous research revealed the social factors and hazards associated with urban street trees but the elements that influence was not known. The objectives are: to investigate the elements of the social factors and to determine the influence of these elements towards hazardous street trees. 480 questionnaires distributed among expert and public within 9 city councils. The findings revealed that 5 elements that influence the hazardous street trees; uncontrollable street planting, tree vandalism, near to neighbourhood context, lack of public awareness and poor nursery stock and failure care.
\end{abstract}

Keywords: Street trees; hazards; influencing; failure trees;

eISSN 2398-4279 @ 2018. The Authors. Published for AMER ABRA cE-Bs by e-International Publishing House, Ltd., UK. This is an open access article under the CC BY-NC-ND license (http://creativecommons.org/licenses/by$n c-n d / 4.0)$. Peer-review under responsibility of AMER (Association of Malaysian Environment-Behaviour Researchers), ABRA (Association of Behavioural Researchers on Asians) and cE-Bs (Centre for EnvironmentBehaviour Studies), Faculty of Architecture, Planning \& Surveying, Universiti Teknologi MARA, Malaysia.

DOI: https://doi.org/10.21834/ajqol.v3i12.144 


\subsection{Introduction}

The past decade saw many local authorities in Malaysia involved in greening and beautification programs. To balance the city development with green space, National Landscape Department (NLD) has issues a National Landscape Policy (NLP) which aimed at making Malaysia the Beautiful Garden Nation by 2020. The Ministry of Housing and Local Government through the NLD work towards developing and protecting the sustainable green infrastructure as an effort to establish a healthy, conducive and quality environment for improving the people's quality of life (National Landscape Policy, 2010). One of the missions of NLP was planting a total twenty million trees by the year of 2020 (Noriah, 2004). To achieve the mission, the Ministry of Federal Territories has launched a program to plant 1,970 trees in the Federal Territories in conjunction with National Landscape Day and 37,000 trees to be planted in three Federal Territories by the year of 2013 (Utusan Malaysia, Jun 13, 2013). The initial programme of 'No Roads Without Trees' set into motion a highly successful and sustained effort to maintain the green environment of the city wherever possible and to bring greenery into the concrete forest via extensive tree planting and landscaping. Among the popular tree species planted such as Peltophorum ptrerocarpum (Yellow flame), Samanea saman (Rain tree), Cinnamomum iners (Kayu manis), Lagerstromea speciosa (Bungor), Ficus benjamina (Beringin), Mimusops elengi (Tanjung), Millettia atropurpurea (Tulang daing), Delonix regia (Red flame) and Swietenia macrophylla (Mahogany) (Sreetheran et, al. 2012).

\subsection{Literature Review}

\subsection{Effects of hazardous trees on public safety and property damage in Malaysia roadside areas}

Nowadays, issues on hazardous street trees have been widespread and can be proved by the public complaint to local authorities and report of newspapers. Maruthaveeran et al., (2010) state that the Malaysia city councils are unaware of the consequences of a tree failure such as property damage and personal injury. In Malaysia, the case related to hazard trees is increased by years. According to Sinar Harian newspaper (April 9, 2015), the incident occurred at Taman Sentosa, Gemas, Negeri Sembilan where is Muhammad Ridduan Abdul Karim are 35 years dead because of violation of fallen trees in its road. Other two passengers of the truck were not injured seriously. In another case, (Sinar Harian newspaper, September $2,2014)$ two teenagers dead after motorcycle had ridden crushed by a fallen tree at Pintasan road, Kuantan. A roadside tree suddenly was fallen and crushed the victims and motorcycle during the good weather with no rain or strong winds. Firefighters help to remove the bodies from the tree branches before they were sent to the hospital. Public Relations Officer of the Fire and Rescue Department took about half an hour to cut the branches and cleaning areas to avoid traffic jam. According to Sinar Harian newspaper (July 10, 2015), seven cars damaged by fallen trees at Sultan Abdul Halim and Sultan Badlishah road at Alor Setar, Kedah. The incident occurred when heavy rain with strong wind caused a lot of tree's branches fallen to the cars. Berita Harian newspaper (Mei 8, 2015) reported four vehicles 
were crushed by a big tree at Landai road, Pudu Plaza, Kuala Lumpur. Eight members of Fire and Rescue deployed to the scene and Kuala Lumpur City Hall (DBKL) management to carry out the work of cutting and removing trees. Berita Harian newspaper (June 4, 2014) others cases occurred at Kuantan, Pahang where is one vehicle crushed by a tree when the weather is goods. Kuantan Municipal Council (MPK) verified that trees falling due to the central trunk are rotten. Sinar Harian newspaper (August 14, 2012), a matured Fragrea fragrance (tembusu) crushed to nine cars at parking area in Taman Tasek Seremban. After the case occurs, Seremban Municipal Council works hard to clean up the branches of that fallen tree.

\subsection{Social Factors and Elements Influencing hazardous street trees}

Previous literature search (Jacqueline et al., 2011; Dexter et al., 2011; Billie and Robert 2002) shows that there are five factors that affect the hazardous street trees which are site factor, social factor, economic factor, species selection factor and management factor occur in Malaysia urban area. Unlike the other factors, social factors are the main important factors that influence the hazardous street trees, and this factor can be seen clearly in everyday life. Social factors are the aspects that directly influence or affect lifestyles and behaviour in social situations. Figure 2.1 and Table 2.1 show the social factors and elements influencing hazardous street trees.

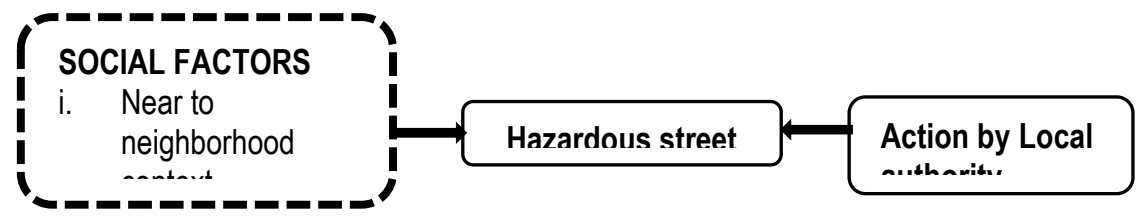

Fig. 2.1: Social Factors that influence the hazardous street trees

(Source : Authors)

Table 2.1. Explanation for Social factors

\begin{tabular}{|c|c|c|}
\hline Elements & Explanations & Source \\
\hline $\begin{array}{l}\text { Near to neighbourhood } \\
\text { context }\end{array}$ & $\begin{array}{l}\text { The location of the street trees close to } \\
\text { residential area, commercial area, } \\
\text { community activity area (night market, stall). }\end{array}$ & $\begin{array}{l}\text { Yvonne et al. (2006), Rachel } \\
\text { (1983), Rebekah et al.(1997) }\end{array}$ \\
\hline $\begin{array}{l}\text { Uncontrollable street } \\
\text { tree planting }\end{array}$ & $\begin{array}{l}\text { Unhealthy or unsuitable or fruit trees } \\
\text { donated by NGO's and related agencies to } \\
\text { planting at the roadside. }\end{array}$ & $\begin{array}{l}\text { Stephanie (2010), Geoffrey and } \\
\text { David (2010) }\end{array}$ \\
\hline Trees vandalism & $\begin{array}{l}\text { An irresponsible person who destruction of } \\
\text { street trees such as nailing the tree and } \\
\text { binding advertising on the tree. }\end{array}$ & $\begin{array}{l}\text { Emma and Charlie(2014), Marvin } \\
\text { (1978), Emily(2013) }\end{array}$ \\
\hline $\begin{array}{l}\text { Lack of public } \\
\text { awareness }\end{array}$ & $\begin{array}{l}\text { Lack of understanding of street tree } \\
\text { management, unaware about street tree } \\
\text { species selection, poor knowledge of tree } \\
\text { maintenance such as tree pruning and } \\
\text { fertilizing. }\end{array}$ & $\begin{array}{l}\text { Charlie et al.(2016), Lauren et al. } \\
\text { (2016), Mariella et al.(2016),Ruth } \\
\text { et al.(2010),Jim (1990) }\end{array}$ \\
\hline $\begin{array}{l}\text { Poor nursery stock and } \\
\text { failure care }\end{array}$ & $\begin{array}{l}\text { Poor quality of trees, root defects, lack } \\
\text { adequate care after planting. }\end{array}$ & $\begin{array}{l}\text { Edward and Laura (2007), Mark } \\
\text { (2002),Michael and Douglas } \\
\text { (2009), James (2001),Kim et }\end{array}$ \\
\hline
\end{tabular}


(Source : Authors)

Previous researches have discussed social problems and hazards associated with urban street trees including fears of crime, disease, insects and other animals (Dwyer et al., 1992; Joy et al., 2012). Inadequate root systems and other physical defects, incorrect irrigation practices, poor preparation, poor planting, nutritional deficiency, and insect damage effects the stressful of nursery conditions (James, 2001). The unhealthy street tree usually in poor conditions, did not receive professional pruning (Daphne, 2014), and diminish their value for communities. The right tree in the right place in the roadside area will reduce public outages, retain the beauty of scenic roads and reduce roadside maintenance costs (Thomas, 2016). A Large tree is one of the major causes of power outages in areas of overhead utility lines due to direct tree contact with lines, or to trees or tree limbs falling on the lines. When trees contact live wires, they become conductors of electricity, causing power outages or creating dangerous situations for anyone coming into contact with the trees. Furthermore, the tree can often cause minor damage to footpaths, street curbs, pave and driveways. Tree roots can sometimes damage similar lightweight structures such as boundary walls if they are in direct contact with the footings of the wall. Also, tree roots rarely cause structural damage to buildings in commercial and residential areas (Yvonne et al. 2006). This is because the footings of the buildings are usually deep and substantial and not easily moved or damage by roots. A matured tree has large roots near the base of the trunk that provide the structural support the tree requires to stay upright. If these roots occur in a restricted space between the footing of a building and some other solid object such as bedrock, it is possible for a root to cause movement in the foundation or footing of a building as it grows over time. Recently, trees along several Malaysia urban roadsides were vandalized. Emma and Charlie (2014), also mentioned that street trees are vulnerable to vandalism and damage, especially when small, which constraints the flow of benefits they provide and increase the costs of planting programs. Element on awareness of street tree management and pests generally are rare and very little work has been done around awareness of public and professionals (Hurley et al., 2012). Few studies discuss that tree experts have general awareness of the street tree pest issue, but less of the specific knowledge needed for identifying symptoms of disease or infestation. Additional literature shows that there are low levels of awareness of invasive species in general amongst public and professionals (Marzano et al., 2015). In term of lack of public awareness of their knowledge, increasing numbers of new pest and disease and the growing complexity of pathways (Pautasso et al,2010; Stenlid et al, 2011; Eschen et al., 2015), cause of the level of awareness amongst the professional and public may be less than ideas (Mariella et al., 2016).

\subsection{Social benefits provided by urban street trees for improving quality of life}

According to Roy et al. (2012), urban street trees have been found to provide social, economic, health, visual and aesthetic benefits to human. In 115 research papers on urban trees examined in their study, $6 \%$ are examined social benefits, with five demonstrating an 
actual benefit which was often associated with increased quality of human life. Among its interests are making urban environment more pleasant to live, work and spend leisure time, providing significant outdoor leisure, providing nature in the city, enhancing quality of urban life, promoting environmental responsibility and ethnics, building stronger sense of community, enhancing community's sense of social identity and self-esteem, providing settings for significant emotional and spiritual experiences and providing opportunities for inner city children to experience nature.

\subsection{Methodology}

A review of the literature is conducted among other things to determine a theoretical gap exists (Gregory et al. (2007).A literature review was conducted to study and present the factors and the issues related to the research. As explained by Merriam (1998), the literature review will help to identify the major studies and factors effects of the research. Next, the methodology used is structured designed questionnaires to collect the response from the experts and public. Research questions were developed through a review of the literature. Section A of questionnaire consists of the demographic background of the respondent. Section $B$ consists of set of question-related to effects of hazardous street trees to public and properties. Section $\mathrm{C}$ of the questionnaire consist of a list of important factors and element to be ranked by respondents based on factors influencing hazardous trees occurs using Likert scale from $1-5$. The higher number represents the higher important factors of the element. Field observation and pilot test of the survey questionnaire were done to obtain information on the improvement of the questionnaire. The 40 expert's respondents are landscape architects and arborists at local authority while the selection of 440 public respondents based on their knowledge related to the research. The selection of the public respondents consists of landscape architecture students, an employee in landscape architecture fields and academicians. The selection of the respondents is based on their voluntarily and their knowledge about street trees. The collected data were analyzed statistically using the Statistical Packaging for Social Science (SPSS) version 20.

\subsection{Results and Discussion}

Table 4.1 shows the ranking of mean score for social factors' elements. The analysis shows that the most influential element based on the mean score is uncontrollable street tree planting (mean score $=4.43$ ). The second influential element for social factors is tree vandalism may increasing value (mean score $=4.17$ ). The third influential element for social factors is near to neighbourhood context (mean score $=4.14$ ). Lack of public awareness (mean score $=4.05$ ) stands at $4^{\text {th }}$ ranking and lastly is poor nursery stock and failure care (mean score $=3.78)$.

Table 4. 1. Ranking of mean results for social factors

\begin{tabular}{lll}
\hline Social factor & Mean & Rank \\
\hline Element & & \\
\hline
\end{tabular}


Hasan, R., et.al. / Asian Journal of Quality of Life (AjQoL), 3(12) Jul / Aug 2018 (p.77-85)

\begin{tabular}{lll}
\hline Uncontrollable street tree planting & 4.43 & 1 \\
Trees vandalism & 4.17 & 2 \\
Near to neighbourhood context & 4.14 & 3 \\
Lack of public awareness & 4.05 & 4 \\
Poor nursery stock and failure care & 3.78 & 5 \\
\hline
\end{tabular}

(Source : Authors)

Note: Likert Rating Scale

1= Strongly disagree, 2= Disagree, 3=Moderate, 4=Agree, 5= Strongly agree

Table 4. 2. Response on social factor influence that hazardous street trees occur

\begin{tabular}{|c|c|c|c|c|c|c|c|c|c|c|}
\hline \multirow[t]{2}{*}{ Element } & \multicolumn{2}{|c|}{$\begin{array}{l}\text { Near to } \\
\text { neighbourhood } \\
\text { context }\end{array}$} & \multicolumn{2}{|c|}{$\begin{array}{l}\text { Uncontrollable } \\
\text { street tree } \\
\text { planting }\end{array}$} & \multicolumn{2}{|c|}{ Trees vandalism } & \multicolumn{2}{|c|}{$\begin{array}{l}\text { Lack of public } \\
\text { awareness }\end{array}$} & \multicolumn{2}{|c|}{$\begin{array}{l}\text { Poor nursery } \\
\text { stock and } \\
\text { failure care }\end{array}$} \\
\hline & $\bar{f}$ & $\%$ & $\bar{f}$ & $\%$ & $f$ & $\%$ & $\bar{f}$ & $\%$ & $\bar{f}$ & $\%$ \\
\hline $\begin{array}{l}\text { Strongly } \\
\text { disagree }\end{array}$ & 0 & 0 & 0 & 0 & 0 & 0 & 0 & 0 & 39 & 8.1 \\
\hline Disagree & 33 & 6.9 & 8 & 1.7 & 0 & 0 & 39 & 8.1 & 8 & 1.7 \\
\hline Moderate & 92 & 19.2 & 39 & 8.1 & 111 & 23.1 & 1 & .2 & 57 & 11.9 \\
\hline Agree & 129 & 26.9 & 168 & 35.0 & 173 & 36.0 & 336 & 70.0 & 290 & 60.4 \\
\hline $\begin{array}{l}\text { Strongly } \\
\text { agree }\end{array}$ & 226 & 47.1 & 265 & 55.2 & 196 & 40.8 & 104 & 21.7 & 86 & 17.9 \\
\hline Total & 480 & 100 & 480 & 100 & 480 & 100 & 480 & 100 & 480 & 100 \\
\hline
\end{tabular}

Table 4.2 highlights the total number of responses on the social factor elements that influence the hazardous street trees. The highest $265(55.2 \%)$ respondents strongly agree for uncontrollable street tree planting, $290(60.4 \%)$ respondents agree that poor nursery stock and failure care as the influencial elements for the hazardous street trees. Meanwhile, 111 $(23.1 \%)$ respondents moderately agree that tree vandalism is the influencial element the hazardous street trees occur.

Table 4.3. Mean Score among Public respondents on the Social Factor Elements

\begin{tabular}{lllllll}
\hline Element & $\begin{array}{l}\text { Mean } \\
\text { Governme } \\
\text { nt sector }\end{array}$ & $\begin{array}{l}\text { Private } \\
\text { sector }\end{array}$ & $\begin{array}{l}\text { Local } \\
\text { authority }\end{array}$ & $\begin{array}{l}\text { Studen } \\
\mathrm{t}\end{array}$ & Total & $\begin{array}{l}\text { Ra } \\
\text { nk }\end{array}$ \\
\hline $\begin{array}{l}\text { Uncontrollable street tree } \\
\text { planting }\end{array}$ & 4.53 & 4.44 & 4.47 & 4.13 & 4.43 & 1 \\
$\begin{array}{l}\text { Trees vandalism } \\
\text { Near to neighborhood context }\end{array}$ & 4.24 & 4.13 & 4.22 & 4.16 & 4.17 & 2 \\
$\begin{array}{l}\text { Lack of public awareness } \\
\text { Poor nursery stock and failure } \\
\text { care }\end{array}$ & 4.13 & 4.02 & 4.22 & 4.23 & 4.14 & 3 \\
\hline
\end{tabular}

(Source : Authors)

Table 4.3 shows the ranking of the comparison means results for element influences the social factors. The analysis shows that the most important influential element based on the ranking of the mean result is uncontrollable street planting (total mean $=4.43$ ). The second 
influential element for social factor is tree vandalism (total mean $=4.17$ ). The third influential element is the location of street trees are near to neighbourhood context (total mean = 4.14).The lack of public awareness element stands at $4^{\text {th }}$ ranking with a total mean result of 4.05 under the social factors. Next, poor nursery stock and failure care (total mean $=3.78$ ) is the lowest rank in social factors.

Table 4.4. Comparison of mean score among Malaysia City Councils on the Social Factor Elements

\begin{tabular}{|c|c|c|c|c|c|c|c|c|c|}
\hline Element & $\begin{array}{l}\text { Mean } \\
\text { KLCH }\end{array}$ & $\begin{array}{l}\text { KTC } \\
\mathrm{C}\end{array}$ & SACC & MCC & ASCC & PICC & $\mathrm{JBCC}$ & ICC & PJCC \\
\hline $\begin{array}{l}\text { Uncontrollable } \\
\text { street tree } \\
\text { planting }\end{array}$ & 5.00 & 3.00 & 4.80 & 5.00 & 2.00 & 4.00 & 5.00 & 5.00 & 4.00 \\
\hline Trees vandalism & 4.00 & 3.00 & 4.80 & 5.00 & 5.00 & 4.00 & 5.00 & 5.00 & 5.00 \\
\hline $\begin{array}{l}\text { Near to } \\
\text { neighborhood } \\
\text { context }\end{array}$ & 4.00 & 3.00 & 4.80 & 5.00 & 3.00 & 4.00 & 5.00 & 5.00 & 4.80 \\
\hline $\begin{array}{l}\text { Lack of public } \\
\text { awareness }\end{array}$ & 5.00 & 2.00 & 4.80 & 4.00 & 4.00 & 4.00 & 4.00 & 4.00 & 5.00 \\
\hline $\begin{array}{l}\text { Poor nursery } \\
\text { stock and failure } \\
\text { care }\end{array}$ & 5.00 & 1.00 & 4.80 & 4.00 & 5.00 & 4.00 & 4.00 & 4.00 & 4.00 \\
\hline
\end{tabular}

(Source : Authors)

Note: KLCH=Kuala Lumpur City Hall, KTCC=Kuala Terengganu City Council, SACC $=$ Shah Alam City Council,

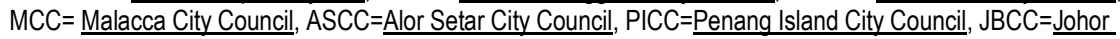
Bahru City Council, ICC $=$ Ipoh City Council, $P J C C=$ Petaling Jaya City Council

Table 4.4 shows the ranking based on the mean score responses between the Nine City Councils in Malaysia were selected as respondents. The expert's respondents consist of landscape architects and arborists. From the analysis, KLCH, MCC, JBCC, ICC stated that (mean=5.00) for the element of uncontrollable street tree planting. Next, SACC stated same mean for all the elements (mean $=4.80$ ) also PICC stated same mean for all elements (mean $=4.00)$. KTCC stated the lowest mean for poor nursery stock and failure care (mean $=1.00)$ and ASCC stated (mean $=2.00$ ) for uncontrollable street tree planting.

\subsection{Conclusion}

This paper has elaborated on the significant of street trees management by the local authority for city development. Trees versus element of social factors are inseparable and need to give attention to the parties responsible. The investigation shows that the social factors comprised of 5 elements which are uncontrollable street tree planting, tree vandalism, planted near to neighbourhood context, lack of public awareness and poor nursery stock and failure care. This study also revealed that uncontrollable street tree planting is elements that strongly influence the hazardous street trees. Hence, the increasing of fallen street trees by years can be avoided when the public are concerned on the social factors' elements that influence the 
hazardous street trees occurs. In additions, the local authority can be more proactive by controlling the selection of street trees species and ensuring that it is planted in accordance to the guideline and specification provided by National Landscape Department. This is due to the fact that urban street trees have been found to provide social, economic, health, visual and aesthetic benefits to human, associated with increased quality of human life.

\section{Acknowledgement}

Authors gratefully acknowledge and grateful for the financial support of the Geran Inisiatif Penyelidikan (GIP) by Universiti Teknologi MARA for this research. Special thanks also to the reviewers for their invaluable comments on this paper.

\section{References}

Andrew K. K., Edward F. G., Maria P. and Chris H. (2014). Factors influencing urban tree planting program growth and survival in Florida, United States.

Beatty, R.A., Heckman, C.T., (1981). Survey of urban tree programs in the United States.Urban Ecol. 5, 81-102.

Billie G.C. and Robert J. D.(2002). The relative influence of individual, social and physical environment determinants of physical activity. Social Science \& Medicine Volume 54, Issue 12, Pages 1793-1812

Dwyer, J., McPherson, E., Schroeder, H., Rowntree, R., 1992. Assessing the benefits and costs of the urban forest. Journal of Arboriculture 18, 227-234

Daphne M. (2014). San Francisco's Street Trees in Poor Shape as City Shifts Upkeep to Residents.

Edward f. G. and Laura S. (2007). Selecting quality trees from the nursery.

Gilman, E.F., Black, R.J., Dehgan, B., (1998). Irrigation volume and frequency and tree size affect establishment rate. J. Arboriculture. 24, 1-9.Harris, J.R., Gilman, E.F., (1993). Production method affects growth and posttransplant establishment of 'East Palatka' holly. J. Am. Soc. Hortic. Sci. 118,194-200.

Jacqueline W.T. L., Erika S. S., Lindsay K. C., Jennifer G., Jessie B., Kristen L. K., and Nancy F.R.

(2010).Biological, Social, and Urban Design Factors Affecting Young Street Tree Mortality in New York City. Cities and the Environment. 3(1) article 5.

James A. S.(2001). The contribution of imperfections in nursery stock to the decline of young vines in California.

Phytopathol. Mediterr 40, Supplement, S369-S375

Jones, R.H., Chappelka, A.H., West, D.H., (1996). Use of plastic shelters for the low-cost establishment of street trees. Southern J. Appl. Forest. 20, 85-89.

Lara A.R., Lindsey A. W., Catherine M. M., David J. M., Susan A. M., Winnie H. (2015).Stewardship matters: Case studies in establishment success of urban trees. Urban Forestry \& Urban Greening Volume 14, Issue 4, Pages 1174-1182 
Leibowitz, R., (2012). Urban tree growth and longevity: an international meeting and research symposium white paper. Arboriculture. Urban Forest. 38, 237-241.

Lemaire, F., Rossignol, J.P., (1999). Stress factors related to urban soils. Acta Hortic.496, 347-351.

Impens, R.A., (1999). Life conditions and stress for urban trees, an example of Brussels City. Acta Hortic. 496, 301307.

Maruthaveeran, S (2010). The Perception of Social Safety in a Green Environment. A Preliminary Study at the Kepong Metropolitan Park. Asian Journal of Environment-Behaviour Studies. 1 (2):33-48

Maco, S.E., McPherson, E.G., (2003). A practical approach to assessing structure, function, and value of street tree populations in small communities. J. Arboriculture. 29, 84-97.

Mark H. (2002).Getting started in the Nursery Business.

Noriah, O.(2004). A Cross-Cultural Comparison of Preferences towards Selected Urban Landscape Planting Compositions. Unpublished thesis, Universiti Teknologi MARA

Nowak, D.J., Kuroda, M., Crane, D.E.(2004). Tree mortality rates and tree population projections in Baltimore, Maryland, USA. Urban Forest. Urban Green. 2, 139-147.

Nowak, D.J., McBride, J.R., Beatty, R.A. (1990). Newly planted street tree growth and mortality. J. Arboriculture. 16, 124-129.

Ramly, H., Noriah, O., and Faridah, I. (2016). Roadside Tree Management in Selected Local Authorities for Public Safety. Procedia-Social and Behavioral Sciences, 234, 218-227.

Sudipto R., Jason B. and Catherine P. (2012). A systematic quantitative review of urban tree benefits, costs, and assessment methods across cities in different climatic zones. Urban Forestry \& Urban Greening 11 (2012) 351- 363

Thomas Worthley (2016). Roadside Tree \& Forest Management. Ever source Energy Center 